INSTITUTE

FOR ADVANCED

STUDIES

LUCCA

ISSN 2279-6894

IMT LUCCA EIC WORKING

PAPER SERIES 03

May 2012

Do Eco-Innovations Harm Productivity Growth through Crowding Out?

Results of an Extended CDM Model for Italy

Giovanni Marin 
ISSN 2279-6894

IMT LUCCA EIC WORKING PAPER SERIES \#03/2012

(C) IMT-Institutions, Markets, Technologies, Institute for Advanced Studies, Lucca

Piazza San Ponziano 6, 55100 Lucca

Research Area

Economics and institutional change

\section{Do Eco-Innovations Harm Productivity Growth through Crowding Out?}

\section{Results of an Extended CDM Model for Italy}

\section{Giovanni Marin}

IMT Institute for Advanced Studies Lucca 


\title{
Do Eco-Innovations Harm Productivity Growth through Crowding Out?* Results of an Extended CDM Model for Italy
}

\author{
Giovanni Marin ${ }^{\dagger}$
}

\begin{abstract}
This paper discusses the results for Italy of a CDM model (Crepon et al, 1998) further extended with the objective of evaluating drivers and productivity effects of environmental innovations. The particular nature of environmental innovations, especially as regards the need of government intervention to create market opportunities, is likely to affect the way through which they are pursued (innovation equation within the CDM model) and their effect on productivity (productivity equation).

Here I test two main hypothesis: (i) to what extent polluting firms rely on own innovations to improve their environmental performance? (ii) do the pursue of environmental innovations reduce the likelihood of obtaining other profitable innovations (crowding out)? Results, based on administrative data (AIDA by Bureau van Dijk and patent data from PATSTAT) show that innovation efforts of polluting firms and sectors is significantly biased towards environmental innovations and that environmental innovations tend to crowd out other more profitable (at least in the short run) innovations.
\end{abstract}

Keywords: patents, CDM model, eco-innovation, crowding out JEL: L60, O30, Q55

\section{Introduction}

Technological progress, together with structural change and shifts in consumption patterns, has been acknowledged to be a crucial factor in achieving environmental sustainability (Jaffe et al, 2002; Popp et al, 2009; Popp,

${ }^{*}$ I thank all the participants to the EuroLIO 2012 Conference 'The Geography of Innovation' (Saint-Etienne, France), the Workshop 'Presente e Futuro dell'Economia dell'Ambiente e delle Risorse Naturali in Italia' (Università di Roma Tor Vergata), the seminars held at IMT Advanced Studies Lucca, Banca d'Italia and Università di Ferrara who gave me useful suggestions and insights. This paper is part of my $\mathrm{PhD}$ thesis. The usual disclaimer applies.

${ }^{\dagger}$ IMT Lucca Advanced Studies, Piazza San Ponziano, 6, 55100 Lucca (Italy). E-mail: giovanni.marin@imtlucca.it 
2010). Technological progress might improve environmental performance both through increased resource efficiency and lower emission intensity in production activities and through the supply new more 'sustainable' products as substitutes to other less efficient products (e.g. energy intensive durable goods). Firms are key actors in the creation, adoption and diffusion of environmental innovations as well as the most important responsible for environmental pressures.

The economic literature on eco-innovation patterns at the micro level focuses to a great extent on the identification of the drivers of eco-innovation by firms with little attention given to the effect of eco-innovation on productivity or financial performance of firms. Moreover, most of these empirical works are based on German firms. Rennings and Ziegler (2004) use data from the German Community Innovation Survey (CIS) finding significant positive effect of environmental organizational measures (EMAS and ISO 14001), market opportunities and R\&D intensity on process and product environmental innovations. Wagner (2007) uses both data on environmental patent applications and self-reported measures of eco-innovation to investigate the effect of environmental management on environmental innovations. Results for German firms show positive effect of EMS adoption on self-reported process environmental innovations and a negative effect on firms' general patenting activity. The paper by Horbach (2008) uses a discrete choice model for German manufacturing firms finding strong positive effects of technology push (knowledge capital), demand pull (social awareness of customers) and environmental policy (either mandatory or voluntary through environmental management tools) factors on environmental innovations. Horbach et al (2011) is the first relevant study investigating the determinants of different fields of environmental innovations. Their analysis, based on the German CIS for 2009, shows that the introduction of innovations aimed at reducing by-products of production activities such as the release of air, water and noise emissions are strongly related to government regulations (current and expected). On the other hand, innovations aimed at reducing material and energy use are driven by cost-savings and resource and energy taxes due to the easier appropriability of the returns from innovation through reductions in production costs. Rave et al (2011) base their analysis on German firms and on their patenting behaviour. The main results highlight the importance of a clear and strict environmental regulatory framework, of possible cost savings due to environmental innovations and of the possibility of creating new markets. Finally, results from a survey conducted by Cainelli et al (2011) show that different types of environmental innovations introduced and adopted by manufacturing firms in Emilia Romagna (Italy) is very strongly correlated to international characteristics (foreign ownership and export propensity) and networking with other firms and institutions.

While environmental innovations are expected to have, by definition, 
a beneficial effect on the environment ${ }^{1}$, their effect on productivity is less straightforward. The conventional wisdom predicts that starting from a situation of optimizing firms, any policy aiming at limiting environmental byproducts of firms will result in a reduction in measured productivity. These productivity losses could be reduced by introducing environmental innovations. However, productivity losses cannot be fully removed and resources devoted to generate or adopt environmental innovations should be diverted from 'optimal' research project with higher expected returns (crowding out). In this respect, Popp and Newell (2009) find significant crowding out of energy R\&D expenditures on general R\&D in those US industries characterized by more than 5 percent of energy R\&D. However, when they consider energy patents at the firm level, evidence is more mixed, with relevant but insignificant crowding out effect.

An alternative view, promoted by Porter and van der Linde (1995), allows for the possibility of win-win outcomes. In this case, environmental regulations help to fill information gaps about available technologies and technological opportunities and they help solving the additional appropriability problem of environmental innovations (EI) due to the fact that EI reduce external, generally not priced, costs ('weak' version of the Porter hypothesis). Moreover, early introduction of environmental technologies is expected to generate early mover advantages for regulated firms, with long run positive effects on competitiveness and, eventually, on measured productivity ('strong' version of the Porter hypothesis) ${ }^{2}$.

In this respect, Rexhauser and Rammer (2011) use the German CIS 2009 to investigate the effect of different types of environmental innovations on German firms' profits. They find that cost-reducing innovations aimed at reducing energy and material input have a positive effect on firms' profitability while regulation-induced environmental innovations, mainly aimed at reducing environmental pressures, have a negative but weak effect on profitability.

The aim of this paper is to assess the drivers of environmental innovations and their effect on firm-level productivity. I employ a panel of Italian manufacturing firms for the period 2000-2007 containing information on balance sheet and income statement, EPO patent applications and polluter status in order to jointly identify the drivers of eco-innovations and their contribution to firm-level productivity. The empirical framework is that of a modified CDM model (Crepon et al, 1998) to account for eco-innovation patterns. The rest of the paper is organized as follows. Section 2 briefly de-

\footnotetext{
${ }^{1}$ Economists and policy makers are increasingly worried about the possibility that cost and price reductions brought by environmental innovations through improvement in material and energy efficiency would result in an increased consumption of these new efficient goods, with an overall negative effect on the environment (rebound effect).

${ }^{2}$ For a more detailed discussion about the difference between the 'strong' and 'weak' version of the Porter hypothesis refer to Jaffe and Palmer (1997).
} 
fines eco-innovation and the extent to which patent data are a useful source of information on eco-innovation. Section 3 focuses on the description of the empirical model and of the data. Section 4 discusses the results. Section 5 concludes.

\section{Definition of environmental innovations and the role of patent data}

A definition of environmental innovation is needed in order to investigate its impact on productivity and potential crowding out effects. There has been a rich debate in the economic literature about the distinctive features of environmental innovations as opposed to general innovations (Rennings, 2000). Environmental innovation (or eco-innovation) has been defined by Kemp and Pearson (2007) within the project 'Measuring Eco Innovation' as

[...] the production, assimilation or exploitation of a product, production process, service or management or business method that is novel to the organisation (developing or adopting it) and which results, throughout its life cycle, in a reduction of environmental risk, pollution and other negative impacts of resources use (including energy use) compared to relevant alternatives.

This is a broad definition, making it difficult to measure environmental innovation in a comprehensive way. On the one hand, survey are able to describe qualitatively the whole spectrum of eco-innovation strategies of innovative firms. On the other hand, however, the broad definition of ecoinnovation is likely to result in ambiguous questions in the questionnaires which are prone to misleading interpretations by surveyed people.

Patent data could act as a more objective alternative to measure ecoinnovation (Oltra et al, 2009). Patents contain rich information about the technological field of the underlying innovation, especially when analysing reported IPC classes and the text contained in the patent or in the abstract. This rich information is generally exploited through the identification of relevant 'environmental' IPC classes and /or through the systematic search of 'environmental' keywords.

Nevertheless, the use of patent data as measure of environmental innovation output within the definition elaborated by Kemp and Pearson (2007) (but also more generally for all innovations ${ }^{3}$ ) is characterized by some serious limitations.

\footnotetext{
${ }^{3}$ Refer to Griliches (1990) for a survey on the advantages and limitations of patent data as a measure of innovation.
} 
First, patents cover just part of the innovation output. Many innovations are not patented either because they cannot be patented ${ }^{4}$ or because firms prefer to use alternative means to protect their innovations (secrecy, lead time, etc.). Moreover, the propensity to use patents as a mean of protecting innovations varies substantially across sectors and across technologies. In general, process innovations, which are very relevant when considering environmental innovations, are under-represented as opposed to product innovations.

Second, information on the ownership and actual use of patented innovations is generally lost after the patent has been granted. Patent data ignore the whole phase of 'adoption' of innovations. It is thus plausible that a share of patented innovations is not even adopted by applicant firms which could act as specialized suppliers of (embodied or disembodied) knowledge to other firms which are the real adopters. A recent paper by Calel and Dechezlepretre (2012), dealing with the assessment of the effect on climate-related patenting of the European Emission Trading Scheme for EU firms, briefly discusses issue of the possible separation between adoption and creation of climate-related innovations. They argue that "economic theory predicts that environmental regulations would produce greater incentive to develop new technologies for directly regulated firms than for third-party technology suppliers" because "the latter are not discharging emissions themselves and receive no private benefit from the new technology" (Calel and Dechezlepretre, 2012, p. 22).

Third, patent data consider only those innovations which are 'new to the market' while they ignore those innovations which are just 'new to the firm' because of the 'novelty' requirement for patented innovations.

Finally, the distribution of the value of patents is very skewed, with a tiny proportion of extremely valuable patents and a great majority of patents with little or even no commercial value (Hall et al, 2007). Finally, patenting firms represent a very small fraction of innovative firms, leading to possibly low robustness of the results and to econometric problems when dealing with excess zeros of patent count indicators.

Despite these limitations, many recent analysis on environmental innovations were based on patent statistics. Among other, refer to Lanjouw and Mody (1996), Popp (2002), Brunnermeier and Cohen (2003), Wagner (2007) and Johnstone et al (2010).

\footnotetext{
${ }^{4} \mathrm{An}$ innovation can be patented if it is novel, non-obvious and commercially viable. Moreover, specific patent offices do not allow to patent specific technologies (e.g. living organisms).
} 


\section{$3 \quad$ Empirical model and data}

Econometric analysis are based on an adaptation of the CDM model (Crepon et al, 1998). The CDM model is an empirical structural econometric model aimed at investigating innovation patterns of firms in a comprehensive way, considering the drivers of innovation inputs (R\&D), their effect on innovation success (innovation output) and the extent to which innovation success affects firm's productivity.

\subsection{Classical and extended CDM model}

\section{Classical CDM model}

The CDM model is an empirical structural model proposed by Crepon et al (1998) to evaluate innovation patterns of firms in a comprehensive way. The model is composed by three steps. In the first step, firms decide whether to undertake formal $\mathrm{R} \& \mathrm{D}$ projects or not and the amount of resources to devote to R\&D activities. The choice of innovation inputs is modelled with an Heckman selection model to account for incidental truncation of the R\&D variable. In a second step, firms use innovation inputs and other internal or external resources to obtain commercially viable innovations. The original CDM model (Crepon et al, 1998) used two alternative measures of innovation output: share of innovative sales (which, in their case, was a categorial variable) and patent applications count (count variable). Other more recent CDM models based on CIS data used alternative measures of innovation output such as the introduction of process and / or product innovations. Finally, successful innovations affect firm's profitability and / or productivity. Innovation output is included in an extended production function as an additional input and its effect on productivity is assessed.

By using predicted values of $R \& D$ and patent counts in the second and third step respectively, the CDM model is a sort of instrumental variable approach to correct for simultaneity and reverse causality issues in the various steps.

\section{R\&D equation}

The first decision of firms about their innovation strategy is whether to perform any formal R\&D and, eventually, its intensity. The CDM model uses a Heckman sample selection model to estimate R\&D intensity. R\&D expenditure is characterized by incidental truncation, with the decision to perform formal $R \& D$ depending on (unobservable) expected returns on $R \& D$ (i.e. whether expected returns exceed $R \& D$ investments). Moreover, $R \& D$ strategies of firms might be modelled as a the two-stage decision process in which firms decide, in a first stage, whether to perform any formal $R \& D$ 
and, in a second stage, its intensity. I estimate the Heckman selection model simultaneously with maximum likelihood.

Explanatory variables for the first step (probability of reporting positive R\&D) are log of employees count, market share, log of capital intensity (fixed physical assets per employee), log of total assets (book value), age (a dummy variable for firms older than 10 years) and sector ${ }^{5}$, year and macro-regional ${ }^{6}$ dummies. I exclude (exclusion restriction) book value and firm's age in the second step (R\&D intensity expressed as the log of R\&D per employee) of the Heckman model, assuming that firm's age and the value of its assets affects the probability of performing R\&D (extensive margin) but not its intensity (intensive margin).

It is important to bear in mind that possible severe measurement errors in the $R \& D$ variable (refer to the Appendix $B$ for further detail on the $R \& D$ variable) are likely to cause a substantially overestimated standard errors.

\section{Patent equation}

The combination of innovation inputs (R\&D) with internal and external resources results in the introduction of innovations. Successful innovations have been measured in CDM models in a variety of ways. Crepon et al (1998) use patent applications count and share of innovative sales as indicators of successful innovations. Other authors (e.g. Hall et al (2009) for Italy and Griffith et al (2006) for France, Germany, Spain and the UK) used dummy variables describing the introduction of innovations, generally distinguishing between process and product innovations. In this paper I use the number of EPO (European Patent Office) patent applications as a measure of innovation output.

Patent data are count data. When the dependent variable is a nonnegative integer, OLS are likely to be biased and they could give rise to negative predicted values. In this model I use a negative binomial (NB2) regression model $^{7}$. The baseline model to deal with count dependent variables is the Poisson model which assumes equidispersion (mean equal to the variance) of the variable of interest. This property is often violated in actual data, which are generally characterized by overdispersion ${ }^{8}$ (Cameron and Trivedi, 1998). I use a Negative Binomial (NB2) model which allows the

\footnotetext{
${ }^{5}$ I classify sectors according to the Pavitt's taxonomy (Pavitt, 1984). Pavitt classifies manufacturing sectors according to their patterns of innovation ending up with four macro-sectors: (i) supplier-dominated sectors; (ii) scale intensive sectors; (iii) specialized suppliers sectors; (iv) science based sectors.

${ }^{6}$ I identify four macro-regions: North-West, North-East, Central Italy and Southern Italy and Islands.

${ }^{7}$ Preliminary attempts have been done with other models which deal explicitly with excess zeros (zero inflated Poisson or NB, hurdle Poisson or NB).

${ }^{8}$ The unconditional variance of total patent count is, in all samples, much higher than the unconditional mean. In the full sample the variance 6.5 time the mean, in the patent sample the variance is 4.47 times the mean and in the polluter sample the variance is
} 
conditional variance of the dependent variable to be a quadratic function of the conditional mean ${ }^{9}$.

The dependent variable of the patent equation is yearly EPO applications count. Explanatory variables are (predicted) log of R\&D per employee, firm size (log of employees), local patent stocks (log of regional patent stocks per capita) and sector, macro-region and year dummies. Innovation input and firm size (Mansfield, 1986) are expected to affect positively the number of patent applications. As regards local patent stock, it might act either as innovation input for firms in the form of local knowledge stock or as potential alternative to internally patented innovations to be adopted through licensing or embodied in machineries and intermediate inputs. These two alternative interpretations affect firm-level patenting activity in opposite directions. Sector dummies (Pavitt's taxonomy) control for sector-specific propensity to apply for a patent. As pointed out by Pavitt (1984), the propensity to use patents as a mean to appropriate the returns to $R \& D$ is high for science-based and specialized suppliers sectors while scale intensive and supplier dominated sectors have lower propensity to patent their innovations ${ }^{10}$. Finally, year and regional dummies control for changes in the propensity to patent through time (due either to changes in firm's strategies or to variations in patent systems) and for geographical differences in human capital, links with local actors in the local innovation systems and innovation capabilities.

\section{Productivity equation}

The final step consists in estimating the effect of successful innovation output on firm's productivity or profitability. I use an extended Cobb-Douglas production function in which the log of labour productivity (value added per employee) is a function of the log capital intensity (fixed physical assets per employee) and the log of (predicted) innovation output (expected number of patent applications per employees). I also include the log of employees as explanatory variable to test for constant returns to scale ${ }^{11}$. I include sector,

13.36 times the mean.

${ }^{9}$ Being $\omega_{i}$ the conditional variance of the count variable, and $\mu_{i}$ its conditional mean, the NB2 model assumes that $\omega_{i}=\mu_{i}+\alpha \mu_{i}^{2}$. In case $\alpha$ is not statistically different from zero, the NB2 model converges to a Poisson model.

${ }^{10}$ Descriptive statistics regarding the sample of firms used in this paper confirm Pavitt's priors about sector-specific propensity to patent: in table 3 I observe a much higher share of firm/year pairs with positive patents in science based and specialized supplier sectors $(4.27 \%$ and $5.14 \%$ respectively) than for scale intensive (1.97\%) and supplier dominated $(0.78 \%)$ sectors.

${ }^{11}$ A general Cobb-Douglas production function with two inputs (labour, $L$, and capital, $K)$ is given by the equation $V A=A K^{\alpha} L^{\beta}$. Constant returns to scale imply that $\alpha+\beta=1$. Dividing both sides by $L$, taking the $\log$ and rearranging I obtain $\log (V A / L)=\log (A)+$ $\alpha \log (K / L)+(\beta+\alpha-1) \log (L)$. Under the assumption of constant returns to scale, the parameter for $\log (L)$ should be zero $(\beta+\alpha=1)$. The same concept applies with more 
year and regional dummies to account for sector, time and region specific productivity shocks. I estimate the productivity equation with OLS.

\section{Extended CDM model}

My extension to the classical CDM model consists into the separation of the innovation output (patent applications count) into two categories: environmental innovations and other innovations ${ }^{12}$. The approach of splitting innovation outcome in multiple categories has been extensively used in CDM models, especially by separating product innovations from process innovations (Hall et al, 2009; Griffith et al, 2006). This extension will result in two different patent equations and in a unique productivity equation in which environmental and non-environmental innovations will have different productivity effects. The separate assessment of the productivity effect of environmental and non-environmental innovations will allow me to (indirectly) test for the presence of crowding out of environmental innovations relative to other innovations ${ }^{13}$.

An additional extension regards the special consideration, as regards environmental innovations, for polluting firms/sectors. Polluting firms and sectors are expected to show a significant and systematic bias towards environmental innovations relative to other firms/sectors. This fact is likely to be reflected in the patent equation, with polluting firms and sectors which will probably apply for a greater number of environmental patents. Table 1 reports the results of a series of Probit regressions in which the dependent variable is the probability of filing for an environmental patent and the explanatory variables the polluter status (either polluting firm or polluting sector) and a series of controls ${ }^{14}$. Estimates has been performed on the sub-sample of observations with positive patent applications count. On average, the probability of being an eco-innovator is greater for polluting firms ('polluter') and polluting sectors, thus highlighting the relative bias of polluting firms and sectors towards eco-innovations relative to other firms and sectors. However, especially when controlling for firm size, the bias of polluting firms becomes statistically insignificant.

\footnotetext{
than two inputs.

${ }^{12}$ Note that, because of the complexity and variety of environmentally-beneficial technologies and of the approach of selecting environmental patents only by means of their IPC class, the non-environmental category of patents is likely to contain a possibly remarkable number of environmental innovations.

${ }^{13}$ Popp and Newell (2009) try to disentangle the presence of crowding out at the firm level in a more direct way. They check whether an increase in energy patent applications at the firm level reduces the number of other patent applications. They implicitly assume that the return of energy patents is (on average) lower than the return of other patents.

${ }^{14}$ Year dummies and macro-region dummies (North-West, North-East, Central Italy and South-Islands), macro-sector dummies (Pavitt's taxonomy), firm-size (log of employees) and patent class dummies (1 patent, 2-5 patents, 6-10 patents, 11-20 patents and 21+ patents).
} 
Figure 1: Kernel distribution of log of employees count

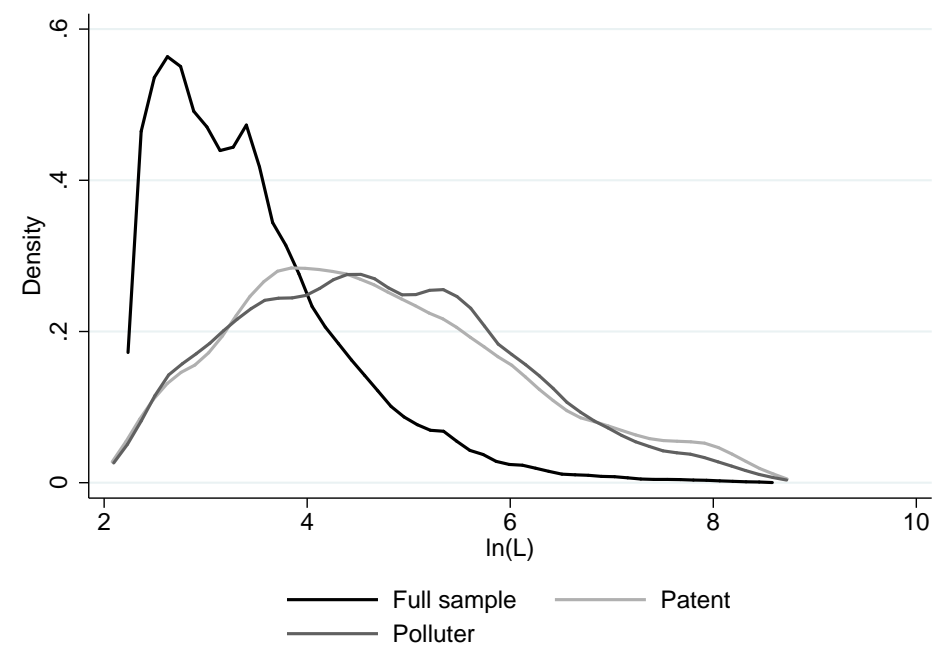

In addition, I aim at investigating whether environmental innovations affect polluting firms in a different way relative to other firms. On the one hand, polluting firms might profit from environmental innovations through their effect on the decrease of compliance costs. On the other hand, however, environmental innovations introduced to reduce compliance costs coupled with constraints in the amount financial resources that a firm can invest in $R \& D$ activities could determine a shift of the innovation strategies of firms towards innovations with lower expected returns. This test is done by interacting the predicted intensity of environmental patents with the dummy indicating that a firm is a polluter in the productivity equations.

\subsection{Data}

This paper uses a dataset containing balance sheet / income statement information on Italian manufacturing firms (AIDA, by Bureau van Dijk) which has been further merged with patent applications to the European Patent Office (EPO). For sake of brevity, refer to Marin (2011) for further details on the methodology used to match EPO applications and firms in AIDA and for some general descriptive statistics. I further extended the AIDA dataset by identifying the biggest polluting firms and the most emission-intensive sectors ${ }^{15}$.

The use of administrative data as an alternative to survey data is a distinctive feature of the current paper as opposed to similar articles either in the CDM literature or in the eco-innovation literature. On the one hand, administrative data give more objective and standardized information on

\footnotetext{
${ }^{15}$ Refer to the Appendix A for further details.
} 
Table 1: Probability of filing for an environmental patent (firm/year pairs with positive patents - Probit estimates, marginal effects are shown)

\begin{tabular}{|c|c|c|c|c|}
\hline All_env & (1) & (2) & (3) & (4) \\
\hline Polluter & $\begin{array}{c}0.0825^{* * *} \\
(0.0186)\end{array}$ & $\begin{array}{c}0.0879^{* * *} \\
(0.0189)\end{array}$ & $\begin{array}{l}0.0275^{*} \\
(0.0155)\end{array}$ & $\begin{array}{c}0.0173 \\
(0.0149)\end{array}$ \\
\hline Polluting_sector & $\begin{array}{c}0.0115 \\
(0.0139)\end{array}$ & $\begin{array}{l}0.00918 \\
(0.0137)\end{array}$ & $\begin{array}{l}0.0322^{*} \\
(0.0170)\end{array}$ & $\begin{array}{c}0.0437^{* *} * \\
(0.0177)\end{array}$ \\
\hline $\begin{array}{l}\text { Polluter } \\
\text { Polluting_sector }\end{array}$ & $\begin{array}{c}0.0819 * * * \\
(0.0187) \\
0.00320 \\
(0.0134) \\
\end{array}$ & $\begin{array}{c}0.0878^{* * *} \\
(0.0191) \\
0.000331 \\
(0.0132) \\
\end{array}$ & $\begin{array}{c}0.0239 \\
(0.0154) \\
0.0287^{*} \\
(0.0169) \\
\end{array}$ & $\begin{array}{c}0.0124 \\
(0.0146) \\
0.0417^{* *} \\
(0.0177) \\
\end{array}$ \\
\hline Pol_waste & (1) & (2) & (3) & (4) \\
\hline Polluter & $\begin{array}{c}0.0254^{* *} \\
(0.0110)\end{array}$ & $\begin{array}{c}0.0259^{* *} \\
(0.0110)\end{array}$ & $\begin{array}{c}0.0149 \\
(0.00994)\end{array}$ & $\begin{array}{c}0.0121 \\
(0.00945)\end{array}$ \\
\hline Polluting_sector & $\begin{array}{c}0.0114 \\
(0.00867)\end{array}$ & $\begin{array}{c}0.0109 \\
(0.00858)\end{array}$ & $\begin{array}{l}0.0188^{*} \\
(0.0112)\end{array}$ & $\begin{array}{l}0.0225^{*} \\
(0.0117)\end{array}$ \\
\hline $\begin{array}{l}\text { Polluter } \\
\text { Polluting_sector }\end{array}$ & $\begin{array}{c}0.0239 * * \\
(0.0108) \\
0.00905 \\
(0.00831) \\
\end{array}$ & $\begin{array}{c}0.0245^{* *} \\
(0.0109) \\
0.00839 \\
(0.00820) \\
\end{array}$ & $\begin{array}{c}0.0130 \\
(0.00964) \\
0.0170 \\
(0.0110) \\
\end{array}$ & $\begin{array}{c}0.01000 \\
(0.00906) \\
0.0210^{*} \\
(0.0115) \\
\end{array}$ \\
\hline Renewables & (1) & (2) & (3) & (4) \\
\hline Polluter & $\begin{array}{c}0.0289^{* *} \\
(0.0116) \\
\end{array}$ & $\begin{array}{c}0.0292^{* *} \\
(0.0116) \\
\end{array}$ & $\begin{array}{c}0.00832 \\
(0.00894) \\
\end{array}$ & $\begin{array}{c}0.00331 \\
(0.00802) \\
\end{array}$ \\
\hline Polluting_sector & $\begin{array}{l}-0.00430 \\
(0.00765)\end{array}$ & $\begin{array}{l}-0.00496 \\
(0.00744)\end{array}$ & $\begin{array}{c}0.00608 \\
(0.00982)\end{array}$ & $\begin{array}{c}0.0106 \\
(0.0102)\end{array}$ \\
\hline $\begin{array}{l}\text { Polluter } \\
\text { Polluting_sector }\end{array}$ & $\begin{array}{c}0.0300^{* *} \\
(0.0118) \\
-0.00653 \\
(0.00723) \\
\end{array}$ & $\begin{array}{c}0.0305^{* *} \\
(0.0119) \\
-0.00727 \\
(0.00700) \\
\end{array}$ & $\begin{array}{c}0.00775 \\
(0.00890) \\
0.00504 \\
(0.00969) \\
\end{array}$ & $\begin{array}{c}0.00242 \\
(0.00788) \\
0.0102 \\
(0.0102) \\
\end{array}$ \\
\hline $\begin{array}{l}\text { Year d. } \\
\text { Macro_reg d. } \\
\text { Size }(\ln (\mathrm{L})) \\
\text { Pavitt d. } \\
\text { Class_patent d. }\end{array}$ & $\begin{array}{l}- \\
- \\
- \\
- \\
-\end{array}$ & $\begin{array}{c}\text { Yes } \\
\text { Yes } \\
- \\
- \\
-\end{array}$ & $\begin{array}{l}\text { Yes } \\
\text { Yes } \\
\text { Yes } \\
\text { Yes } \\
-\end{array}$ & $\begin{array}{l}\text { Yes } \\
\text { Yes } \\
\text { Yes } \\
\text { Yes } \\
\text { Yes }\end{array}$ \\
\hline $\mathrm{N}$ & 5694 & 5694 & 5694 & 5694 \\
\hline
\end{tabular}

Table 2: Descriptive statistics

\begin{tabular}{|c|c|c|c|c|c|c|c|}
\hline Variable & Mean & Q1 & Median & Q3 & Min & $\operatorname{Max}$ & $\mathrm{SD} /$ mean \\
\hline \multicolumn{8}{|c|}{ Full sample } \\
\hline Book value & 13478 & 1800 & 3608 & 8392 & 113.7 & 7795221 & 5.36 \\
\hline Employees & 63.8 & 15 & 26 & 50 & 10 & 4985 & 2.919 \\
\hline Fixed physical assets per empl. & 37.41 & 9.144 & 22.49 & 47.64 & .6339 & 472.5 & 1.228 \\
\hline Value added per empl. & 47.21 & 33.23 & 41.32 & 54.21 & 10.2 & 237.2 & .4831 \\
\hline Age & 20.05 & 11 & 18 & 26 & 0 & 107 & .6629 \\
\hline R\&D per empl. & 1.937 & .08979 & .3252 & 1.198 & $2.18 \mathrm{e}-06$ & 529.7 & 4.193 \\
\hline Perform R\&D (d.) & .3184 & 0 & 0 & 1 & 0 & 1 & 1.463 \\
\hline Regional patent stock pc & .539 & .3602 & .5676 & .7812 & .01131 & .8801 & .4869 \\
\hline \multicolumn{8}{|c|}{ Patent sample } \\
\hline Total patents & 2.092 & 1 & 1 & 2 & 1 & 44 & 1.461 \\
\hline Environmental patents (all) & .1507 & 0 & 0 & 0 & 0 & 25 & 4.498 \\
\hline Pollution and waste patents & .03548 & 0 & 0 & 0 & 0 & 3 & 6.057 \\
\hline Renewable energy patents & .04689 & 0 & 0 & 0 & 0 & 25 & 8.895 \\
\hline
\end{tabular}

firms. Balance sheet and income statement are compulsory and they are compiled according to transparent and standard compulsory criteria by all firms. These information are likely to be generally more reliable than corresponding self-reported information. However, standardization goes together with simplification of available information, limiting substantially the scope 
Table 3: Sectoral distribution of observations (sub-section Nace Rev. 1.1 and Pavitt (1984) taxonomy)

\begin{tabular}{|c|c|c|c|c|c|}
\hline Sector & Full sample & Patent sample & Perc w/pat & Polluter sample & Perc pollut \\
\hline DA & 18245 & 88 & $0.48 \%$ & 348 & $1.91 \%$ \\
\hline DB & 19812 & 135 & $0.68 \%$ & 283 & $1.43 \%$ \\
\hline DC & 8115 & 67 & $0.83 \%$ & 81 & $1.00 \%$ \\
\hline $\mathrm{DD}$ & 6212 & 23 & $0.37 \%$ & 78 & $1.26 \%$ \\
\hline $\mathrm{DE}$ & 15434 & 103 & $0.67 \%$ & 481 & $3.12 \%$ \\
\hline DF-DG & 11082 & 520 & $4.69 \%$ & 1058 & $9.55 \%$ \\
\hline $\mathrm{DH}$ & 14173 & 465 & $3.28 \%$ & 181 & $1.28 \%$ \\
\hline DI & 14461 & 111 & $0.77 \%$ & 849 & $5.87 \%$ \\
\hline DJ & 52915 & 942 & $1.78 \%$ & 2244 & $4.24 \%$ \\
\hline DK & 35990 & 1843 & $5.12 \%$ & 216 & $0.60 \%$ \\
\hline DL & 21657 & 914 & $4.22 \%$ & 187 & $0.86 \%$ \\
\hline DM & 6698 & 227 & $3.39 \%$ & 127 & $1.90 \%$ \\
\hline DN & 18499 & 256 & $1.38 \%$ & 280 & $1.51 \%$ \\
\hline Scale intensive manuf. & 88946 & 1752 & $1.97 \%$ & 3452 & $3.88 \%$ \\
\hline Science based manuf. & 26006 & 1110 & $4.27 \%$ & 1192 & $4.58 \%$ \\
\hline Specialized suppliers manuf. & 42024 & 2160 & $5.14 \%$ & $\begin{array}{c}118 \\
218\end{array}$ & $0.52 \%$ \\
\hline Supplier dominated goods & 86317 & 672 & $0.78 \%$ & 1551 & $1.80 \%$ \\
\hline Total & 243293 & 5694 & $2.34 \%$ & 6413 & $2.64 \%$ \\
\hline
\end{tabular}

Figure 2: Kernel distribution of log of book value

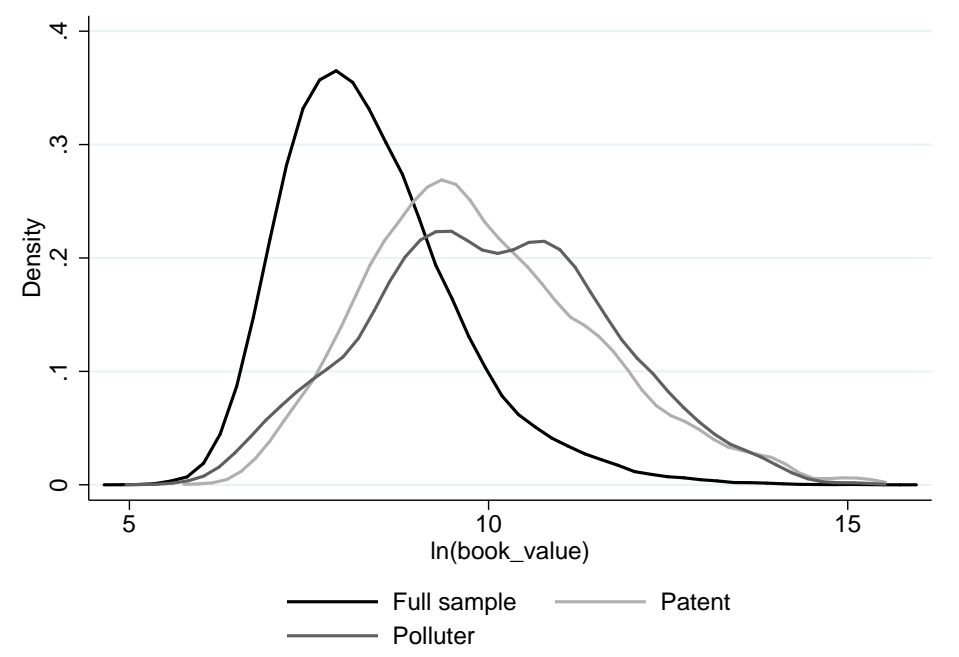

of possible empirical analysis as opposed to survey data. Besides missing qualitative information (e.g. innovation strategies, skill composition of labour force, perceptions of market and regulatory conditions), many important monetary variables are not shown in either balance sheet or income statement, such as investment, R\&D expenditure (refer to the Appendix B for further detail on the $R \& D$ asset variable reported in the balance sheet), composition of sales by product for multi-product firms, export and other relevant information. Finally, selection issues in administrative databases are slightly different relative to survey data. In general, firms are selected 
Figure 3: Kernel distribution of log of value added per employee

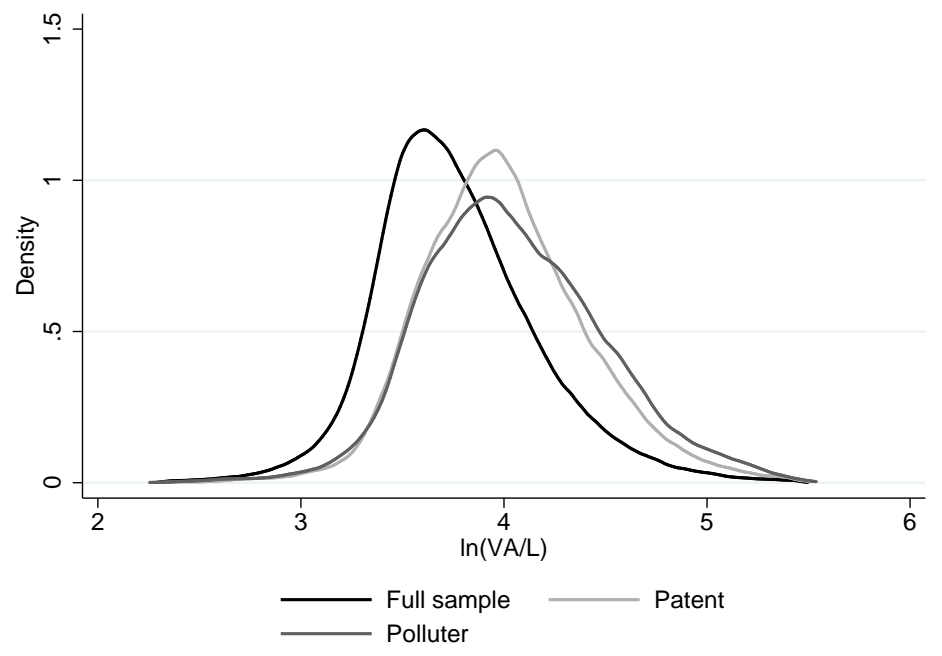

into an administrative database (e.g. AIDA) according to specific criteria ${ }^{16}$ and, in theory, the 'response rate' is expected to be 100 percent ${ }^{17}$.

In this paper I focus on firm/year pairs with more than ten employees and with less than 5000 employees $^{18}$. Moreover, I removed some observations because of missing values in relevant variables and outlier observations ${ }^{19}$. The classical and extended CDM models are estimated for three distinct samples: (i) full sample; (ii) sub-sample including firm/year pairs with positive patents (patent sample); (iii) sub-sample including polluting firms only (polluter sample). The distribution of observations by sectors

\footnotetext{
${ }^{16}$ In this paper I use AIDA TOP which includes, in theory, all registered companies with more than 1.5 million euros of sales and a sample (about 10 percent of population) of registered companies with less than 1.5 million euros of sales. Individual firms are excluded and inactive firms are dropped from the database after four consecutive years of inactivity.

${ }^{17}$ Coverage of balance sheet and income statement information in AIDA is actually not complete, with a quite substantial share of firms with a limited time coverage.

${ }^{18}$ Even though results with all firms are very similar to those reported here, the choice of excluding very small and very big firms is motivated by the possibility that very small family companies and huge groups are characterized by extremely different innovation patterns. The thresholds are, however, somehow arbitrary. Finally, results excluding the upper and lower tails of the size distribution of firms are more easily comparable with those of innovation surveys which generally exclude that kind of firms.

${ }^{19}$ Outliers were identified according to the following criteria: sales per employee smaller than 2000 euros or greater than 10000 euros, growth rate of sales greater than 150 percent or smaller than -150 percent, growth rate of employees greater than 150 percent or smaller than 50 percent, growth rate of fixed physical assets greater than 200 percent or smaller than -50 percent, growth rate of labour productivity (value added per employee) greater than 300 percent or smaller than -90 percent, first and last percentile of sales per employee, value added per employee and fixed physical assets.
} 
for the three different samples is reported in table 3 . Table 2 reports some descriptive statistics for the full sample and, for patent statistics, for the patent sample. It is worth noting that just 32 percent of firm/year pairs have positive $R \& D$ (71 percent for the patent sample and 53 percent for the polluter sample), which motivates the use of the Heckman selection model to correct for sample selection bias. Another interesting information concerns the distribution of patents: in most of the cases (65 percent) firms just file for one patent per year and several firms (about one quarter) file for just one patent during the considered period. Finally, about 15 percent of considered patents have been classified as 'environmental patents'.

Figures 1, 2 and 3 show, respectively, the kernel distribution (Epanechnikov kernel function) of log of employees count, log of book value and log of value added per employee for the three samples. Firms with positive patents and with big polluting plants are substantially bigger than other firms. Moreover, polluting firms tend to be slightly bigger than firms with patents $^{20}$. Looking at the distribution of labour productivity, I observe a clear evidence that patenting firms and polluting firms are generally more productive than other firms. This is not surprising as regards patenting firms, because I expect that either patents improve productivity through technological improvement and temporary market power and (or) that more productive firms are more likely to file for patents. However, firms with big polluting plants seem to be even more productive, on average, than patenting firms, with a fatter right tail. This evidence, which might seem surprising at a first look, could depend on the peculiar sectoral distribution of polluting firms, especially concentrated in scale-intensive sectors.

EPO patent applications were sorted by priority year. Environmental patents were identified according to their IPC $\operatorname{class}^{21}$. I use two different sources of environmentally-relevant IPC classes: the IPC Green Inventory ${ }^{22}$ by the World Intellectual Property Organization (WIPO) and the Indicator of Environmental Technology ${ }^{23}$ (ENV-Tech Indicator) by the OECD. The selection of environmentally-related IPC classes by the OECD is much narrower relative to the selection by the $\mathrm{WIPO}^{24}$. In the sample of matched patent applications used in the current paper, environmental patent ap-

\footnotetext{
${ }^{20}$ This is not surprising given that firms listed on the EPER and E-PRTR need to pass certain thresholds related to the size of their production plants.

${ }^{21}$ The article by Lanjouw and Mody (1996) was an early effort to identify environmental patents to investigate their international diffusion. Recent empirical analysis based on environmental patents (among others, Rave et al (2011) and Johnstone et al (2010)) combined both IPC class selection and keywords search in patent abstracts and/or titles to identify environmental innovations. The approach of focusing on IPC classes only is likely to underestimate the number of environmental patents, thus giving rise to more conservative estimates.

${ }^{22}$ http://www.wipo.int/classifications/ipc/en/est/

${ }^{23} \mathrm{http}$ ://www.oecd.org/environment/innovation/indicator/

${ }^{24}$ I excluded those IPC classes referring to nuclear energy technologies.
} 
plications identified according to the ENV-Tech Indicator (OECD) were about one third of environmental patent applications identified according to the IPC Green Inventory (WIPO). Moreover, environmentally relevant IPC classes identified by the WIPO already cover most of the IPC classes selected by the Env-Tech Indicator. In this paper I use three different selections of environmental patent applications: (i) environmental patents identified as environmentally relevant by either WIPO or OECD (aggr); (ii) environmental patents in the field of renewable energy (renew); (iii) environmental patents in the field of waste and pollution management (poll).

Patent stocks per capita at the regional level were computed by using data on EPO patent applications count (based on applicants) reported in the OECD Database 'Patents by region' (OECD, 2011). The stock is computed by means of a perpetual inventory method (the initial year was set to 1990 and the yearly geometric depreciation rate was set to 15 percent as suggested by Hall (2006)).

The rest of the variables used in the current paper comes from the AIDA database. In absence of data on investments, I used book-value fixed capital assets as a proxy for capital stock while to approximate R\&D effort I used capitalized $\mathrm{R} \& \mathrm{D}$ available in the section 'intangible assets' of the balance sheet. I retrieved total assets (book value of the firm) from the balance sheet and value added and sales from the income statement. Employees count, firm's age, location and main sector of activity are provided by Bureau van Dijk. Additional information on manipulation and definition of these variable is reported in the Appendix A.

\section{Results}

In this section I discuss the results of the econometric analysis, with a specific focus on drivers and productivity effect of environmental patents. All estimates include sector (Pavitt's taxonomy), macro-region and year dummies: results for these variables are not shown but remain available upon request. For all estimates based on the full sample, standard errors have been clustered by firm, while for the patent and polluter sub-samples, standard errors have been clustered by sector (Nace Rev. 1.1 2-digit), region (NUTS-2) and year. Moreover, results including bootstrap standard errors to account for the fact that $\mathrm{R} \& \mathrm{D}$ (second step) and patents (third step) are estimated values are very similar.

\subsection{Classical CDM model}

Before moving to the results on eco-innovation patterns, it is worth discussing the outcome of the classic CDM model. The first step (R\&D equation - table 4) shows a significant selection bias (the correlation of disturbances between first and second step of the Heckman, $\rho$, is negative and 
Table 4: First step: R\&D equation

\begin{tabular}{|c|c|c|c|c|c|c|}
\hline & \multicolumn{2}{|c|}{ Full sample } & \multicolumn{2}{|c|}{ Patent } & \multicolumn{2}{|c|}{ Polluter } \\
\hline Dep: $\ln (\mathrm{R} \& \mathrm{D} / \mathrm{L})$ & OLS & Heckman & OLS & Heckman & OLS & Heckman \\
\hline $\ln (\mathrm{L})$ & $\begin{array}{c}-0.0992^{* * *} \\
(0.0142)\end{array}$ & $\begin{array}{c}-0.685^{* * *} \\
(0.0239)\end{array}$ & $\begin{array}{c}-0.180 * * * \\
(0.0258)\end{array}$ & $\begin{array}{c}-0.433^{* * *} * \\
(0.0340)\end{array}$ & $\begin{array}{c}-0.103^{* * *} \\
(0.0395)\end{array}$ & $\begin{array}{c}-0.474^{* * *} \\
(0.0460)\end{array}$ \\
\hline Market_sh & $0.855^{* * *}$ & $2.516^{* * *}$ & $0.995^{*}$ & $2.801^{* * *}$ & 0.215 & $0.506^{*}$ \\
\hline $\ln (\mathrm{K} / \mathrm{L})$ & $0.128^{* * *}$ & 0.00818 & $0.139^{* * *}$ & $0.102^{* * *}$ & $0.328^{* * *}$ & $0.184 * * *$ \\
\hline & $(0.0126)$ & (0.0138) & $(0.0337)$ & $(0.0380)$ & $(0.0420)$ & $(0.0456)$ \\
\hline Constant & $-1.319^{* * *}$ & $3.230^{* * *}$ & $-0.386^{*}$ & $1.827^{* * *}$ & $-2.215^{* * *}$ & $1.781^{* * *}$ \\
\hline & $(0.0797)$ & $(0.163)$ & $(0.222)$ & $(0.269)$ & $(0.270)$ & $(0.354)$ \\
\hline Perform R\&D & \multicolumn{2}{|c|}{ Full sample } & \multicolumn{2}{|c|}{ Patent } & \multicolumn{2}{|c|}{ Polluter } \\
\hline $\ln (\mathrm{L})$ & & $\begin{array}{c}0.143^{* * *} \\
(0.0114)\end{array}$ & & $\begin{array}{l}-0.0758 \\
(0.0515)\end{array}$ & & $\begin{array}{c}0.0905^{* *} \\
(0.0357)\end{array}$ \\
\hline Market_sh & & $-1.847^{* * *}$ & & $-2.081^{* * *}$ & & $-0.350^{* *}$ \\
\hline $\ln (\mathrm{K} / \mathrm{L})$ & & $-0.0234 * * *$ & & $-0.0461^{* *}$ & & 0.0154 \\
\hline & & $(0.00585)$ & & $(0.0210)$ & & $(0.0241)$ \\
\hline $\ln$ (book_value) & & $0.426 * * *$ & & $0.378^{* * *}$ & & $0.234^{* * *}$ \\
\hline Age $>10$ & & $\begin{array}{c}(0.00987) \\
0.0212^{*}\end{array}$ & & $\begin{array}{c}(0.0458) \\
0.0683\end{array}$ & & $\begin{array}{c}(0.0315) \\
-0.0834 * *\end{array}$ \\
\hline & & $(0.0126)$ & & $(0.0486)$ & & $(0.0388)$ \\
\hline Constant & & $\begin{array}{c}-4.658^{* * *} * \\
(0.0568)\end{array}$ & & $\begin{array}{c}-2.742^{* * *} \\
(0.243)\end{array}$ & & $\begin{array}{c}-2.884^{* * *} \\
(0.157)\end{array}$ \\
\hline Chi sq & & 1235.0 & & 239.2 & & 284.1 \\
\hline sigma & & 2.407 & & 2.193 & & 2.492 \\
\hline rho & & -0.731 & & -0.808 & & -0.803 \\
\hline lambda & & -1.758 & & -1.771 & & -2.002 \\
\hline Chi sq (rho) & & $1112.1 * * *$ & & $224.1 * * *$ & & $201.6^{* * *}$ \\
\hline Log likelihood & -162806.1 & -283964.1 & -8257.8 & -11200.0 & -7206.1 & -11060.6 \\
\hline $\mathrm{N}$ & 77470 & 243293 & 4052 & 5694 & 3415 & 6413 \\
\hline
\end{tabular}

Table 5: Second step: Patent equation (All patents)

\begin{tabular}{lccc}
\hline & Full & Patent & Polluter \\
\hline $\ln (\widehat{\mathrm{R} \& \mathrm{D}} / \mathrm{L})$ & 0.262 & $0.356^{* * *}$ & $0.904^{* *}$ \\
$\ln (\mathrm{L})$ & $(0.199)$ & $(0.0728)$ & $(0.412)$ \\
& $1.229^{* * *}$ & $0.456^{* * *}$ & $1.290^{* * *}$ \\
$\ln ($ reg_pat_stock_pc $)$ & $(0.131)$ & $(0.0284)$ & $(0.179)$ \\
& 0.112 & $0.136^{* *}$ & 0.0644 \\
Constant & $(0.142)$ & $(0.0578)$ & $(0.401)$ \\
& $-9.427^{* * *}$ & $-2.417^{* * *}$ & $-9.728^{* * *}$ \\
& $(0.953)$ & $(0.356)$ & $(2.293)$ \\
\hline Chi sq & 3202.5 & 1311.9 & 419.2 \\
alpha & 10.25 & 0.228 & 10.95 \\
Log likelihood & -29051.5 & -9631.0 & -2213.9 \\
$\mathrm{~N}$ & 243293 & 5694 & 6413 \\
\hline Standard errors in parentheses & & \\
$* \mathrm{p}<0.1, * * \mathrm{p}<0.05, * * * \mathrm{p}<0.01$ & &
\end{tabular}

significantly different from zero) in OLS estimates for all samples. The probability of reporting positive $R \& D$ intangible assets is positively and significantly related to firm size both in terms of employees count (insignificant for the patent sample only) and book value (log of total assets). The positive effect of firm size on the probability of performing $R \& D$ is a standard result in CDM models: bigger firms are more likely to be willing to incur the initial sunk costs of R\&D activities, they have easier access to credit and they are more capable of bearing the risk related to R\&D investments whose returns are highly uncertain. Moreover, the book value of the firm measured with total assets is a key criterion for the type of reporting system 
Table 6: Third step: productivity equation (All patents)

\begin{tabular}{lccc}
\hline Dep: $\ln (\mathrm{VA} / \mathrm{L})$ & Full & Patent & Polluter \\
\hline $\ln (\mathrm{K} / \mathrm{L})$ & $0.118^{* * *}$ & $0.101^{* * *}$ & $0.187^{* * *}$ \\
& $(0.00132)$ & $(0.00685)$ & $(0.00873)$ \\
$\ln ($ patent $/ \mathrm{L})$ & $0.381^{* * *}$ & $0.431^{* * *}$ & $0.114^{* * *}$ \\
& $(0.0108)$ & $(0.0669)$ & $(0.0335)$ \\
$\ln (\mathrm{L})$ & $0.00595^{* * *}$ & $0.320^{* * *}$ & $0.0517^{* * *}$ \\
& $(0.00191)$ & $(0.0453)$ & $(0.00541)$ \\
Constant & $6.368^{* * *}$ & $3.925^{* * *}$ & $3.961^{* * *}$ \\
& $(0.0883)$ & $(0.0863)$ & $(0.267)$ \\
\hline $\mathrm{R}$ sq & 0.211 & 0.182 & 0.322 \\
$\mathrm{~F}$ & 1664.3 & 57.44 & 123.4 \\
$\mathrm{~N}$ & 243293 & 5694 & 6413 \\
\hline $\mathrm{Standard}$ errors in parentheses & \\
$* \mathrm{p}<0.1, * * \mathrm{p}<0.05, * * * \mathrm{p}<0.01$ &
\end{tabular}

chosen by the firm (refer to Appendix B for further details). As expected, $R \& D$ intensity is negatively related to firm size (log of employees count), with big firms characterized by a relatively lower R\&D intensity than small firms ${ }^{25}$. Market share is negatively related to the probability of performing $\mathrm{R} \& \mathrm{D}$ while it affects its intensity positively. On the one hand, firms holding a dominant market position have little incentive to innovate and they prefer to defend their dominant position rather than exploring new markets or changing their production technology. This idea is in line to the "creative destruction' theory (Aghion and Howitt, 1992) according to which technological leaders have no incentive to further innovate because they would destroy their own current rents. On the other hand, however, once they decide to innovate, there is strong incentive to exploit the current large customer base (product innovations) by introducing new products. When considering process innovations, the incentive depend on the fact that the expected unitary cost savings is spread on a large scale of production. Capital intensity is generally negatively related to the probability of performing formal R\&D (except for polluting firms) but affects R\&D intensity positively (not significantly for the full sample). The negative effect on the binary choice about R\&D might be explained by the greater incentive to increase physical assets in absence of knowledge assets, which require substantial initial sunk costs. However, in case a firm invests in knowledge capital (R\&D), complementarity between knowledge and physical assets seems to arise. Finally, older firms have higher probability to perform R\&D in the full and patent (although insignificantly) samples while older polluting firms have lower propensity to perform R\&D relative to younger polluting firms.

The second step (table 5) has been performed by including the predicted $\log$ of R\&D intensity into a patent equation estimated with a Negative Binomial regression (NB2 version, with the variance of the disturbance expressed as a quadratic function of the conditional mean). I report estimated

\footnotetext{
${ }^{25}$ For a detailed discussion on the relationship between firm size and $\mathrm{R} \& \mathrm{D}$ and patents refer to Cohen and Klepper (1996).
} 
coefficients which can be interpreted as semi-elasticities for logarithmic independent variables (expected relative changes in patent applications count for a relative change in the independent variable) and, for dummy variables (once exponentiated) as relative change in patent applications count when the variable switches from zero to one (Cameron and Trivedi, 1998) ${ }^{26}$.

R\&D intensity affects positively innovation output expressed as patent applications count, the effect being insignificant in the full sample only. The absence of significance for the full sample may depend on the extremely high proportion of observations with no patent applications in the full sample (97.7 percent) relative to the polluter sample (93 percent of observations with no patent) and the patent sample (all observations with positive patents $)^{27}$. The relative sensitivity to $R \& D$ intensity is greater for the polluter sample than for the patent sample. This result may relate to a greater effect of R\&D intensity on the extensive margin (probability of patenting) relative to the extensive margin (number of patents).

Firm size plays a positive role also for innovation output conditional on innovation input (R\&D) due to the generally higher propensity to file for patents for big than for small innovative firms. A greater sensitiveness to firm size for the full and polluter sample than for the patent sample may also depend on different effects of firm size on intensive and extensive margins. Firm size affects patent propensity very strongly (intensive margin) while the elasticity of patent counts (extensive margin) with respect to firm size, conditional on patenting (patent sample), is lower than one, with small patenting firms holding, on average, more patents per employee relative to big firms. Finally, regional patent stock per capita turns out to be positively related to firms' innovation output ${ }^{28}$.

The third step (table 6) contains the predicted expected patent applications count as explanatory variable (more precisely, the log of expected patent applications per employee). Predicted innovation success affects positively and significantly labour productivity, the effect being greater in the full and patent samples (elasticity of about 0.4 ) relative to the polluter sample (elasticity of about 0.1 ). This means that the value of each patent in terms of productivity improvement in polluting firms is about one quarter of the value of each patent for the full sample. This great divergence may partly depend on the bias of polluting firms towards technological domains characterized by lower productivity potential such as environmental innovations, thus confirming the concerns about the possibility to observe crowding

\footnotetext{
${ }^{26}$ More detailed results such as marginal effects are not reported but available upon request.

${ }^{27} \mathrm{R} \& \mathrm{D}$ is insignificant for the full sample also when considering the choice to file for patents as a dichotomous choice (yes/no).

${ }^{28}$ The investigation of knowledge spillovers is not the core of the current analysis. A proper investigation would require more refined measures of local knowledge stocks such as spatially weighted regional stocks.
} 
Table 7: Second step: Patent equation (all environmental patents)

\begin{tabular}{|c|c|c|c|c|c|c|}
\hline & \multicolumn{2}{|c|}{ Full sample } & \multicolumn{2}{|c|}{ Patent } & \multicolumn{2}{|c|}{ Polluter } \\
\hline & No_env & Env & No_env & Env & No_env & Env \\
\hline $\ln (\widehat{\mathrm{R} \& \mathrm{D}} / \mathrm{L})$ & $\begin{array}{c}0.248 \\
(0.200)\end{array}$ & $\begin{array}{c}0.272 \\
(0.319)\end{array}$ & $\begin{array}{c}0.328^{* * *} \\
(0.0726)\end{array}$ & $\begin{array}{c}0.812^{* * *} \\
(0.201)\end{array}$ & $\begin{array}{c}0.947^{* *} \\
(0.425)\end{array}$ & $\begin{array}{c}2.421^{* * * *} \\
(0.892)\end{array}$ \\
\hline $\ln (\mathrm{L})$ & $\begin{array}{c}1.222^{* * *} * \\
(0.131)\end{array}$ & $\begin{array}{c}1.215^{* * *} \\
(0.207)\end{array}$ & $\begin{array}{l}0.446^{* * *} \\
(0.0286)\end{array}$ & $\begin{array}{c}0.612^{* * *} \\
(0.0774)\end{array}$ & $\begin{array}{c}1.315^{* * *} \\
(0.180)\end{array}$ & $\begin{array}{c}1.933^{* * *} \\
(0.454)\end{array}$ \\
\hline ln(reg_pat_stock_pc) & 0.139 & -0.0768 & $0.159^{* * *}$ & -0.213 & -0.00723 & $1.216^{* *}$ \\
\hline Poll (air) & (0.140) & $\begin{array}{c}(0.215) \\
-0.306 \\
(0.520)\end{array}$ & $(0.0602)$ & $\begin{array}{l}(0.155) \\
-0.427 \\
(0.288)\end{array}$ & $(0.407)$ & $\begin{array}{l}(0.497) \\
-0.206 \\
(0.298)\end{array}$ \\
\hline Poll (water) & & $\begin{array}{l}0.0772 \\
(0.553)\end{array}$ & & $\begin{array}{l}-0.365 \\
(0.224)\end{array}$ & & $\begin{array}{c}0.102 \\
(0.311)\end{array}$ \\
\hline Poll (haz_waste) & & 0.613 & & $\begin{array}{c}0.247 \\
(0.281)\end{array}$ & & $\begin{array}{l}-1.050 \\
(0.695)\end{array}$ \\
\hline Poll (no_haz_waste) & & $\begin{array}{c}-0.0580 \\
(0.457)\end{array}$ & & $\begin{array}{c}0.223 \\
(0.317)\end{array}$ & & $\begin{array}{l}0.550^{*} \\
(0.318)\end{array}$ \\
\hline Poll (other) & & $\begin{array}{c}0.0788 \\
(0.654)\end{array}$ & & $\begin{array}{c}-1.265^{*} \\
(0.761)\end{array}$ & & $\begin{array}{l}-1.330 \\
(0.994)\end{array}$ \\
\hline Polluting_sect & & $\begin{array}{c}-0.620^{* * * *} \\
(0.207)\end{array}$ & & $\begin{array}{c}0.132 \\
(0.163)\end{array}$ & & $\begin{array}{c}-2.250^{* * *} \\
(0.461)\end{array}$ \\
\hline Constant & $\begin{array}{c}-9.629 * * * \\
(0.986)\end{array}$ & $\begin{array}{c}-10.70^{* * *} \\
(1.482)\end{array}$ & $\begin{array}{c}-2.578^{* * *} \\
(0.373)\end{array}$ & $\begin{array}{c}-4.012^{* * *} \\
(0.935)\end{array}$ & $\begin{array}{c}-9.560 * * * \\
(2.329)\end{array}$ & $\begin{array}{c}-20.34^{* * *} \\
(3.687)\end{array}$ \\
\hline $\begin{array}{l}\text { Chi sq } \\
\text { alpha }\end{array}$ & $\begin{array}{c}3152.1 \\
10.43\end{array}$ & $\begin{array}{l}701.4 \\
28.38\end{array}$ & $\begin{array}{c}1164.2 \\
0.245\end{array}$ & $\begin{array}{l}207.3 \\
3.898\end{array}$ & $\begin{array}{l}430.3 \\
11.01\end{array}$ & $\begin{array}{c}2013.8 \\
14.40\end{array}$ \\
\hline Log likelihood & -27620.1 & -3807.6 & -9457.4 & -2252.6 & -2086.0 & -428.6 \\
\hline $\mathrm{N}$ & 243293 & 243293 & 5694 & 5694 & 6413 & 6413 \\
\hline
\end{tabular}

out.

The elasticity of value added per employee with respect to capital intensity (fixed physical assets per employee) is positive and significant. Under the assumption of perfect competition and constant returns to scale, the elasticity of labour productivity with respect to capital intensity should represent the capital share of labour income ${ }^{29}$. Capital share tends to be substantially greater for polluting firms relative to other firms probably due to the concentration of polluting firms in scale-intensive sectors. Firms in the patent sample are characterized by strong increasing returns to scale (the log of employee counts is significantly greater than zero and its magnitude is quite relevant). This result, not found for the other samples, might be caused by the temporary market power assigned to patent applicants as a consequence of IPRs protection.

Most of the results of the classical CDM model confirm prior expectations and give a reasonable description of innovation patterns of Italian manufacturing firms.

\subsection{Extended CDM model}

Results for the second step (Patent equation) regarding environmental patents are reported in table 7 . The effect of the various explanatory variables on

\footnotetext{
${ }^{29}$ Firm-level estimates of production functions tend underestimate the share of capital stock relative to national accounting measures in which capita receive about one third of national income. This bias is generally related to attrition problems and to measurement errors in the capital stock (Eberhardt and Helmers, 2010).
} 
Table 8: Third step: productivity equation (All environmental patents)

\begin{tabular}{|c|c|c|c|c|c|}
\hline & \multicolumn{2}{|c|}{ Full sample } & \multicolumn{2}{|c|}{ Patent } & \multirow{2}{*}{$\frac{\text { Polluter }}{(1)}$} \\
\hline Dep: $\ln (\mathrm{VA} / \mathrm{L})$ & (1) & (2) & (1) & (2) & \\
\hline $\ln (\mathrm{K} / \mathrm{L})$ & $\begin{array}{l}0.117^{* * *} \\
(0.00133)\end{array}$ & $\begin{array}{l}0.115^{* * *} \\
(0.00133)\end{array}$ & $\begin{array}{c}0.0975 * * * \\
(0.00724)\end{array}$ & $\begin{array}{c}0.0975^{* * *} \\
(0.00708)\end{array}$ & $\begin{array}{l}0.198^{* * * *} \\
(0.00836)\end{array}$ \\
\hline $\ln (\widehat{\text { no_env }} / \mathrm{L})$ & $\begin{array}{c}0.420 * * * \\
(0.0131)\end{array}$ & $\begin{array}{l}0.433^{* * *} \\
(0.0132)\end{array}$ & $\begin{array}{c}0.328^{* * *} \\
(0.0807)\end{array}$ & $\begin{array}{l}0.303 * * * \\
(0.0802)\end{array}$ & $\begin{array}{c}0.0676^{* * *} \\
(0.0253)\end{array}$ \\
\hline $\begin{array}{l}\ln (\widehat{\operatorname{env}} / \mathrm{L}) \\
\text { polluter } \times\end{array}$ & $\begin{array}{c}-0.0308 * * * \\
(0.00552)\end{array}$ & $\begin{array}{c}-0.0455^{* * *} \\
(0.00568) \\
-0.0183^{*}\end{array}$ & $\begin{array}{c}0.0824 * * \\
(0.0347)\end{array}$ & $\begin{array}{c}0.0733^{* *} \\
(0.0351) \\
-0.0383^{* *}\end{array}$ & $\begin{array}{c}-0.0152^{* * *} \\
(0.00534)\end{array}$ \\
\hline $\begin{array}{l}\ln (\widehat{\text { env }} / L) \\
\text { polluter }\end{array}$ & & $\begin{array}{c}(0.0101) \\
-0.0521 \\
(0.0997)\end{array}$ & & $\begin{array}{c}(0.0183) \\
-0.228 \\
(0.139)\end{array}$ & \\
\hline $\ln (\mathrm{L})$ & $\begin{array}{c}0.00510 * * * \\
(0.00194)\end{array}$ & $\begin{array}{c}0.000740 \\
(0.00196)\end{array}$ & $\begin{array}{c}0.307 * * * \\
(0.0465)\end{array}$ & $\begin{array}{c}0.280 * * * \\
(0.0472)\end{array}$ & $\begin{array}{c}0.0421 * * * \\
(0.00493)\end{array}$ \\
\hline Constant & $\begin{array}{c}6.409^{* * * *} \\
(0.0924)\end{array}$ & $\begin{array}{l}6.377^{* * *} \\
(0.0925)\end{array}$ & $\begin{array}{c}4.156^{* * *} \\
(0.128)\end{array}$ & $\begin{array}{c}4.111 * * * \\
(0.130)\end{array}$ & $\begin{array}{c}3.439^{* * * *} \\
(0.221)\end{array}$ \\
\hline $\begin{array}{l}\text { Net effect } \\
\text { for polluter }\end{array}$ & & $\begin{array}{c}-0.0639^{* * *} \\
(0.0109)\end{array}$ & & $\begin{array}{c}0.0340 \\
(0.0396)\end{array}$ & \\
\hline $\mathrm{R}$ sq & 0.211 & 0.214 & 0.183 & 0.184 & 0.322 \\
\hline $\mathrm{F}$ & 1564.6 & 1413.6 & 54.97 & 55.88 & 113.0 \\
\hline $\mathrm{N}$ & 243293 & 243293 & 5694 & 5694 & 6413 \\
\hline
\end{tabular}

Table 9: Third step: productivity equation (separate effect for 'env' and 'no_env' - all environmental patents)

\begin{tabular}{|c|c|c|c|c|c|c|}
\hline \multirow[b]{2}{*}{ Dep: $\ln (\mathrm{VA} / \mathrm{L})$} & \multicolumn{2}{|c|}{ Full sample } & \multicolumn{2}{|c|}{ Patent } & \multicolumn{2}{|c|}{ Polluter } \\
\hline & (1) & (2) & (1) & (2) & (1) & (2) \\
\hline $\ln (\mathrm{K} / \mathrm{L})$ & $\begin{array}{c}0.1184 * * * \\
(0.0013)\end{array}$ & $\begin{array}{c}0.1215^{* * *} * \\
(0.0013)\end{array}$ & $\begin{array}{c}0.1028^{* * *} \\
(0.0067)\end{array}$ & $\begin{array}{c}0.1028^{* * *} * \\
(0.0072)\end{array}$ & $\begin{array}{c}0.194 * * * \\
(0.0082)\end{array}$ & $\begin{array}{c}0.211^{* * *} \\
(0.0071)\end{array}$ \\
\hline $\ln ($ no_env $/ L)$ & $\begin{array}{c}0.3868^{* * *} * \\
(0.0112)\end{array}$ & & $\begin{array}{c}0.4114^{* * *} \\
(0.0672)\end{array}$ & & $\begin{array}{c}0.0688^{* * *} * \\
(0.0253)\end{array}$ & \\
\hline $\ln (\mathrm{env} / \mathrm{L})$ & & $\begin{array}{c}0.0266^{* * *} * \\
(0.0049)\end{array}$ & & $\begin{array}{c}0.1449^{* * *} \\
(0.0289)\end{array}$ & & $\begin{array}{c}-0.0154^{* * *} \\
(0.0053)\end{array}$ \\
\hline $\ln (\mathrm{L})$ & $\begin{array}{c}0.0052^{* * *} * \\
(0.0019)\end{array}$ & $\begin{array}{c}0.0356^{* * *} * \\
(0.0017)\end{array}$ & $\begin{array}{c}0.3075^{* * *} * \\
(0.0455)\end{array}$ & $\begin{array}{c}0.1273^{* * *} \\
(0.0196)\end{array}$ & $\begin{array}{c}0.046^{* * *} \\
(0.0048)\end{array}$ & $\begin{array}{c}0.0357^{* * *} * \\
(0.0042)\end{array}$ \\
\hline Constant & $\begin{array}{c}6.4556^{* * *} * \\
(0.0926)\end{array}$ & $\begin{array}{c}3.5538^{* * *} * \\
(0.0514)\end{array}$ & $\begin{array}{c}3.9348^{* * *} \\
(0.0906)\end{array}$ & $\begin{array}{c}4.0052^{* * *} \\
(0.1254)\end{array}$ & $\begin{array}{c}3.610^{* * *} \\
(0.2071)\end{array}$ & $\begin{array}{c}2.885^{* * *} * \\
(0.0685)\end{array}$ \\
\hline $\mathrm{R}$ sq & 0.2109 & 0.2021 & 0.1814 & 0.1792 & 0.3215 & 0.3217 \\
\hline $\mathrm{F}$ & 1662.51 & 1589.53 & 56.64 & 55.88 & 123.09 & 120.94 \\
\hline $\mathrm{N}$ & 243293 & 243293 & 5694 & 5694 & 6413 & 6413 \\
\hline
\end{tabular}

non-environmental patents ('no_env' column) are very similar to those estimated for total patent applications in the classical CDM model for all samples.

Looking at the equation for environmental patents I observe a great heterogeneity across samples. Similarly to non-environmental patents, R\&D intensity has a significant positive effect for the patent and polluter samples only, being positive but insignificant for the full sample. This asymmetry is in line with the one found when considering all patents. Moreover, also in the case of environmental patents, the sensitivity to $R \& D$ intensity is greater for the polluter sample than for the patent sample. However, both in the patent and polluter sample, the sensitivity to R\&D is greater for environmental patents than for non-environmental patents (more than double). Patented environmental innovations seem to be more R\&D-intensive than 
Table 10: Second step: Patent equation (pollution and waste patents)

\begin{tabular}{|c|c|c|c|c|c|c|}
\hline & \multicolumn{2}{|c|}{ Full sample } & \multicolumn{2}{|c|}{ Patent } & \multicolumn{2}{|c|}{ Polluter } \\
\hline & No_env & Env & No_env & Env & No_env & Env \\
\hline $\ln (\widehat{\mathrm{R} \& \mathrm{D}} / \mathrm{L})$ & $\begin{array}{c}0.267 \\
(0.201)\end{array}$ & $\begin{array}{c}-0.279 \\
(0.364)\end{array}$ & $\begin{array}{l}0.352^{* * * *} \\
(0.0731)\end{array}$ & $\begin{array}{c}0.329 \\
(0.294)\end{array}$ & $\begin{array}{l}1.006^{* *} \\
(0.420)\end{array}$ & $\begin{array}{c}0.411 \\
(1.132)\end{array}$ \\
\hline $\ln (\mathrm{L})$ & $1.236^{* * *}$ & $0.731^{* * *}$ & $0.457^{* * *}$ & $0.293^{* * *} *$ & $1.345^{* * *}$ & $0.834^{*}$ \\
\hline & $(0.132)$ & $(0.217)$ & $(0.0285)$ & $(0.109)$ & $(0.181)$ & $(0.502)$ \\
\hline ln(reg_pat_stock_pc) & 0.108 & 0.417 & $0.134^{* *}$ & 0.243 & -0.0213 & $3.113^{* *}$ \\
\hline & $(0.143)$ & $(0.372)$ & $(0.0590)$ & $(0.283)$ & $(0.411)$ & $(1.314)$ \\
\hline Poll (air) & & $\begin{array}{l}1.521^{*} \\
(0.844)\end{array}$ & & $0.900^{* *}$ & & $\begin{array}{c}1.103^{* * *} * \\
(0.370)\end{array}$ \\
\hline Poll (water) & & 0.550 & & 0.344 & & 0.150 \\
\hline & & $(0.611)$ & & $(0.411)$ & & $(0.449)$ \\
\hline Poll (haz_waste) & & $\begin{array}{r}-0.649 \\
(0.718)\end{array}$ & & $\begin{array}{l}-0.654 \\
(0.469)\end{array}$ & & $-1.710^{* * *}$ \\
\hline Poll (no_haz_waste) & & -0.122 & & $\begin{array}{l}(0.469) \\
0.188\end{array}$ & & $\begin{array}{l}(0.657) \\
0.777\end{array}$ \\
\hline Poll (other) & & $\begin{array}{c}(0.592) \\
2.029^{* * *}\end{array}$ & & $\begin{array}{l}(0.540) \\
1.663^{*}\end{array}$ & & $\begin{array}{l}(0.482) \\
1.830^{*}\end{array}$ \\
\hline & & $(0.756)$ & & $(0.949)$ & & $(1.087)$ \\
\hline Polluting_sect & & $\begin{array}{l}-0.290 \\
(0.309)\end{array}$ & & $\begin{array}{c}0.367 \\
(0.270)\end{array}$ & & $\begin{array}{c}-2.496^{* * *} \\
(0.776)\end{array}$ \\
\hline Constant & $\begin{array}{c}-9.457 * * * \\
(0.962)\end{array}$ & $\begin{array}{c}-12.47^{* * *} \\
(2.206)\end{array}$ & $\begin{array}{c}-2.430 * * * \\
(0.361)\end{array}$ & $\begin{array}{c}-6.309^{* * *} \\
(1.665)\end{array}$ & $\begin{array}{c}-9.593 * * * \\
(2.336)\end{array}$ & $\begin{array}{c}-25.98^{* * *} \\
(7.394)\end{array}$ \\
\hline Chi sq & 3193.5 & 383.8 & 1297.4 & 55.89 & 448.3 & 3907.3 \\
\hline alpha & 10.36 & 46.33 & 0.238 & 6.530 & 11.21 & 0.825 \\
\hline Log likelihood & -28627.1 & -1313.1 & -9605.4 & -839.7 & -2173.2 & -122.8 \\
\hline $\mathrm{N}$ & 243293 & 243293 & 5694 & 5694 & 6413 & 6413 \\
\hline
\end{tabular}

Table 11: Third step: productivity equation (pollution and waste patents)

\begin{tabular}{|c|c|c|c|c|c|}
\hline & \multicolumn{2}{|c|}{ Full sample } & \multicolumn{2}{|c|}{ Patent } & Polluter \\
\hline Dep: $\ln (\mathrm{VA} / \mathrm{L})$ & (1) & (2) & (1) & (2) & (1) \\
\hline $\ln (\mathrm{K} / \mathrm{L})$ & $\begin{array}{l}0.115^{* * *} \\
(0.00136)\end{array}$ & $\begin{array}{l}0.114^{* * *} \\
(0.00135)\end{array}$ & $\begin{array}{l}0.101^{* * *} \\
(0.00689)\end{array}$ & $\begin{array}{c}0.0994^{* * *} \\
(0.00680)\end{array}$ & $\begin{array}{c}0.194^{* * *} \\
(0.00823)\end{array}$ \\
\hline $\ln (\widehat{\text { no_env }} / \mathrm{L})$ & $\begin{array}{c}0.598^{* * *} \\
(0.0266)\end{array}$ & $\begin{array}{c}0.612^{* * *} \\
(0.0283)\end{array}$ & $\begin{array}{c}0.358 * * * \\
(0.0672)\end{array}$ & $\begin{array}{c}0.291 * * * \\
(0.0690)\end{array}$ & $\begin{array}{c}0.0687^{* * * *} \\
(0.0243)\end{array}$ \\
\hline $\begin{array}{l}\ln (\widehat{e n v} / \mathrm{L}) \\
\text { polluter } \times\end{array}$ & $\begin{array}{c}-0.0797 * * * \\
(0.00899)\end{array}$ & $\begin{array}{c}-0.0873^{* * *} \\
(0.00977) \\
0.0562^{* * *}\end{array}$ & $\begin{array}{c}0.0671 * * * \\
(0.0246)\end{array}$ & $\begin{array}{c}0.0941^{* * *} \\
(0.0266) \\
-0.0428^{* * *}\end{array}$ & $\begin{array}{c}0.00434 \\
(0.00385)\end{array}$ \\
\hline $\begin{array}{l}\ln (\widehat{\text { env }} / \mathrm{L}) \\
\text { polluter }\end{array}$ & & $\begin{array}{c}(0.0114) \\
0.757^{* * *} \\
(0.134)\end{array}$ & & $\begin{array}{c}(0.0147) \\
-0.321^{* *} \\
(0.138)\end{array}$ & \\
\hline $\ln (\mathrm{L})$ & $\begin{array}{c}-0.0155 * * * \\
(0.00302)\end{array}$ & $\begin{array}{c}-0.0202 * * * \\
(0.00303)\end{array}$ & $\begin{array}{l}0.325^{* * *} \\
(0.0467)\end{array}$ & $\begin{array}{l}0.296 * * * \\
(0.0473)\end{array}$ & $\begin{array}{c}0.0473^{* * *} \\
(0.00498)\end{array}$ \\
\hline Constant & $\begin{array}{c}7.241^{* * *} \\
(0.132)\end{array}$ & $\begin{array}{c}7.286^{* * * *} \\
(0.136)\end{array}$ & $\begin{array}{c}4.160 * * * \\
(0.136)\end{array}$ & $\begin{array}{c}4.234^{* * *} \\
(0.141)\end{array}$ & $\begin{array}{c}3.654^{* * *} \\
(0.215)\end{array}$ \\
\hline $\begin{array}{l}\text { Net effect } \\
\text { for polluter }\end{array}$ & & $\begin{array}{c}-0.0311 * * * \\
(0.0143)\end{array}$ & & $\begin{array}{c}0.0513^{* *} \\
(0.0248)\end{array}$ & \\
\hline $\mathrm{R} s q$ & 0.213 & 0.214 & 0.183 & 0.186 & 0.322 \\
\hline $\mathrm{F}$ & 1564.1 & 1413.2 & 56.70 & 58.26 & 118.1 \\
\hline $\mathrm{N}$ & 243293 & 243293 & 5694 & 5694 & 6413 \\
\hline
\end{tabular}

other innovations probably due to their greater complexity and pervasiveness (Cainelli et al, 2011). Innovation success in the field of environmental technologies is slightly more sensitive to firm size relative to other technologies, especially so for polluting firms. Crossing the hurdle is more difficult for environmental patents than for other patents and bigger firms tend to be much more intensive in environmental patents than small firms. As far as local knowledge stock is concerned, no significant effect is found for the full and patent sample while polluting firms rely to a great extent on local 
Table 12: Second step: Patent equation (renewable energy patents)

\begin{tabular}{|c|c|c|c|c|c|c|}
\hline & \multicolumn{2}{|c|}{ Full sample } & \multicolumn{2}{|c|}{ Patent } & \multicolumn{2}{|c|}{ Polluter } \\
\hline & No_env & Env & No_env & Env & No_env & Env \\
\hline $\ln (\widehat{\mathrm{R} \& \mathrm{D}} / \mathrm{L})$ & $\begin{array}{c}0.265 \\
(0.200)\end{array}$ & $\begin{array}{c}0.108 \\
(0.366)\end{array}$ & $\begin{array}{c}0.343 * * * \\
(0.0724)\end{array}$ & $\begin{array}{c}1.126^{* * *} \\
(0.287)\end{array}$ & $\begin{array}{l}0.870^{* *} \\
(0.417)\end{array}$ & $\begin{array}{l}3.106 * * \\
(1.321)\end{array}$ \\
\hline $\ln (\mathrm{L})$ & $1.233^{* * *}$ & $1.023^{* * *}$ & $0.454^{* * *}$ & $0.620^{* * *}$ & $1.282^{* * *}$ & $2.091^{* * *}$ \\
\hline & $(0.132)$ & $(0.222)$ & $(0.0284)$ & $(0.109)$ & $(0.179)$ & $(0.662)$ \\
\hline ln(reg_pat_stock_pc) & 0.135 & $-0.563^{*}$ & $0.158^{* * *}$ & $-0.745^{* * *}$ & 0.0393 & 1.539 \\
\hline Poll (air) & $(0.144)$ & $(0.300)$ & $(0.0584)$ & $\begin{array}{r}(0.245) \\
-0.0280\end{array}$ & $(0.407)$ & $(0.945)$ \\
\hline & & $(0.481)$ & & $(0.344)$ & & $(0.422)$ \\
\hline Poll (water) & & -0.0411 & & -0.213 & & -0.222 \\
\hline Poll (haz_waste) & & 0.236 & & -0.345 & & 15.48 \\
\hline Poll (no_haz_waste) & & 0.125 & & 0.544 & & $0 . \overline{406}$ \\
\hline Poll (other) & & $-18.76^{* * *}$ & & $-19.56^{* * *}$ & & $\begin{array}{l}(0.446) \\
1.855\end{array}$ \\
\hline Polluting_sect & & $\begin{array}{c}(0.640) \\
-0.716^{* *} \\
(0.357)\end{array}$ & & $\begin{array}{c}(0.897) \\
0.000406 \\
(0.360)\end{array}$ & & $\begin{array}{l}(1.192) \\
-0.260 \\
(1.159)\end{array}$ \\
\hline Constant & $\begin{array}{c}-9.607^{* * *} \\
(0.966)\end{array}$ & $\begin{array}{c}-8.051^{* * *} \\
(1.963)\end{array}$ & $\begin{array}{c}-2.566^{* * *} * \\
(0.359)\end{array}$ & $\begin{array}{c}-2.149 \\
(1.587)\end{array}$ & $\begin{array}{c}-9.591 * * * \\
(2.314)\end{array}$ & $\begin{array}{c}-42.82^{* * *} * \\
(5.788)\end{array}$ \\
\hline Chi sq & 3183.7 & 1297.7 & 1279.8 & 664.0 & 405.5 & - \\
\hline alpha & 10.23 & 54.95 & 0.232 & 8.721 & 11.19 & 1.115 \\
\hline Log likelihood & -28606.7 & -1457.4 & -9573.2 & -933.4 & -2184.7 & -129.5 \\
\hline $\mathrm{N}$ & 243293 & 243293 & 5694 & 5694 & 6413 & 6413 \\
\hline
\end{tabular}

Table 13: Third step: productivity equation (renewable energy patents)

\begin{tabular}{|c|c|c|c|c|c|}
\hline & \multicolumn{2}{|c|}{ Full sample } & \multicolumn{2}{|c|}{ Patent } & \multirow{2}{*}{$\frac{\text { Polluter }}{(1)}$} \\
\hline Dep: $\ln (\mathrm{VA} / \mathrm{L})$ & (1) & $(2)$ & (1) & (2) & \\
\hline $\ln (\mathrm{K} / \mathrm{L})$ & $\begin{array}{c}0.118^{* * *} \\
(0.00134)\end{array}$ & $\begin{array}{l}0.116^{* * *} \\
(0.00133)\end{array}$ & $\begin{array}{l}0.101^{* * *} \\
(0.00685)\end{array}$ & $\begin{array}{c}0.0985 * * * \\
(0.00674)\end{array}$ & $\begin{array}{l}0.186^{* * *} \\
(0.00853)\end{array}$ \\
\hline $\ln (\widehat{\text { no_env }} / \mathrm{L})$ & $\begin{array}{c}0.354^{* * * *} \\
(0.0112)\end{array}$ & $\begin{array}{l}0.347 * * * \\
(0.0109)\end{array}$ & $\begin{array}{c}0.432 * * * \\
(0.0692)\end{array}$ & $\begin{array}{c}0.394 * * * \\
(0.0726)\end{array}$ & $\begin{array}{l}0.114 * * * \\
(0.0338)\end{array}$ \\
\hline $\begin{array}{l}\ln (\mathrm{env} / \mathrm{L}) \\
\text { polluter } \times\end{array}$ & $\begin{array}{c}-0.0119 * * \\
(0.00555)\end{array}$ & $\begin{array}{c}-0.0181^{* * *} \\
(0.00472) \\
0.0131^{*}\end{array}$ & $\begin{array}{l}0.00603 \\
(0.0125)\end{array}$ & $\begin{array}{c}0.0130 \\
(0.0140) \\
-0.00765\end{array}$ & $\begin{array}{c}0.00403^{* * *} \\
(0.00118)\end{array}$ \\
\hline $\begin{array}{l}\ln (\text { env } / L) \\
\text { polluter }\end{array}$ & & $\begin{array}{c}(0.00737) \\
0.266^{* * *} \\
(0.0849)\end{array}$ & & $\begin{array}{c}(0.0138) \\
-0.00812 \\
(0.127)\end{array}$ & \\
\hline $\ln (\mathrm{L})$ & $\begin{array}{c}0.00654^{* * *} \\
(0.00192)\end{array}$ & $\begin{array}{c}0.00293 \\
(0.00193)\end{array}$ & $\begin{array}{c}0.325^{* * *} * \\
(0.0452)\end{array}$ & $\begin{array}{c}0.302^{* * *} \\
(0.0467)\end{array}$ & $\begin{array}{c}0.0507^{* * *} \\
(0.00528)\end{array}$ \\
\hline Constant & $\begin{array}{c}6.046^{* * *} \\
(0.126)\end{array}$ & $\begin{array}{c}5.935 * * * \\
(0.114)\end{array}$ & $\begin{array}{c}3.974^{* * * *} \\
(0.0956)\end{array}$ & $\begin{array}{l}3.975^{* * *} \\
(0.0956)\end{array}$ & $\begin{array}{c}4.030^{* * *} \\
(0.271)\end{array}$ \\
\hline $\begin{array}{l}\text { Net effect } \\
\text { for polluter }\end{array}$ & & $\begin{array}{l}-0.0050 \\
(0.0076)\end{array}$ & & $\begin{array}{c}0.0053 \\
(0.0151)\end{array}$ & \\
\hline $\mathrm{R} s q$ & 0.211 & 0.213 & 0.182 & 0.184 & 0.323 \\
\hline $\mathrm{F}$ & 1565.4 & 1413.8 & 54.38 & 51.92 & 116.4 \\
\hline $\mathrm{N}$ & 243293 & 243293 & 5694 & 5694 & 6413 \\
\hline
\end{tabular}

knowledge for their eco-innovation success. While, on average, polluting firms and sectors have greater propensity to patent in fields related to environmental technologies (see table 1), there is no clear specific pattern when considering the status of the firms in terms of type of 'pollution' (air, water, hazardous and non-hazardous waste). The only significant coefficients are found for 'other polluting firms' (with an average lower level of environmental patenting in the patent sample) and for 'non-hazardous waste firms' (with an average higher level of environmental patenting in the polluter sample). 
Finally, it is interesting to note that while, conditional on patenting (patent sample), firms in polluting sectors have a higher (but again insignificant) propensity to file for environmental patents relative to firms in other sectors, the propensity to file for environmental patents in the full and polluter sample for firms in polluting sectors is much lower due to the general lower propensity to patent for firms operating in these sectors.

Looking a the productivity equations (table 8), I observe a strong positive effect of non-environmental patents on labour productivity, with a coefficient which is slightly greater than that found for all patents in the classical CDM (table 6) for the full sample while it is slightly smaller for the patent and polluter samples. On the other hand, looking at the productivity effect of environmental patents, I observe a significant and negative effect on labour productivity for the full and the polluter samples while the effect turns out to be positive and significant (but substantially smaller than the effect of nonenvironmental patents) for the patent sample ${ }^{30}$. These results, especially the negative signs, are a possible evidence that environmental innovations tends to crowd out resources from other innovations which are more profitable, at least in the short run. The small positive effect of environmental patents for the patent sample could be interpreted as actual crowding out only if the average cost, for example expressed in terms of R\&D inputs, of each additional environmental patents is substantially smaller than the average cost of non-environmental patents. This is not likely to be the case. By computing average marginal effects for the two patent equations I estimate that, on average, an increase of 10 percent in $\mathrm{R} \& \mathrm{D}$ intensity is expected to increase the number of non-environmental patents by 0.06 and the number of environmental patents by 0.0123. Environmental patents turn out to be at the same time 'more costly' (in terms of R\&D input) and less remunerative (in terms of better labour productivity) than non-environmental patents, which suggests the possible presence of a crowding out effect also for the patent sample. Finally, polluting firms within the full and patent sample are more strongly characterized by crowding out than other firms ${ }^{31}$. Polluting firms are expected to face more stringent environmental policies than other firms. This asymmetry in the policy environment forces them to bias their

\footnotetext{
${ }^{30} \mathrm{By}$ construction, predicted patent intensity in terms of environmental and nonenvironmental patents are highly correlated. When including predicted environmental patents only and non-environmental patents only (table 9), I observe that environmental patents affect productivity positively and significantly in the full and patent samples and negatively and significantly in the polluter sample. These results are slightly different from those found in table 6 for environmental patents where the estimated effect of environmental patents is systematically smaller. This could be related to the fact that environmental patents do not affect productivity negatively (full sample) or insignificantly (patent sample) per se but only when controlling for general innovation success of the firm with the only exception of the polluter sample, where the effect is always negative.

${ }^{31}$ The net effect for polluting firms in the patent sample turns out to be still positive but insignificant.
} 
innovation patterns towards less productivity-enhancing innovations (ecoinnovations) to reduce compliance $\operatorname{costs}^{32}$. However, this differential effect I find for polluting firms could be partly related to smaller average returns to innovation output (considering all patents) for polluting firms (refer to table 6) relative to other firms.

Estimates of the second and third steps have been done on subsets of environmental patents, namely pollution and waste management patents (tables 10 and 11) and patents related to renewable energy technologies (tables 12 and 13). Pollution and waste management patents seem to be less 'R\&D intensive' than other types of environmental patents, with predicted R\&D intensity being always insignificant, as well as less sensitive to firm size in all samples. Differently from the full set of environmental patents, I found a very strong bias towards pollution and waste patents for firms with a high level of air pollution while local knowledge stock is a relevant input for environmental innovations in polluting firms only. Looking at the productivity equation, patents in the fields of pollution and waste have an effect which is similar to that found for the full set of environmental patents with two notable differences. First, the crowding out in the full sample is now mitigated rather than exacerbated for polluting firms. Second, the effect in the polluter sample is now insignificant. The reduction of compliance costs due to environmental innovations may partly mitigate the crowding out effect for polluting firms with particularly emission and waste intensive production plants.

Finally, looking at patents in renewable energy technologies, their sensitivity to R\&D intensity and firm size is very similar to that one estimated for the full set of environmental patents. The productivity effect of renewable energy patents is negative or insignificant (positive, significant but negligible for the polluter sample). This result is somehow striking, especially when considering the recent rapid growth of the markets for this kind of technologies and by policy measures aimed at favouring the diffusion and adoption of these technologies. Moreover, renewable energy technologies are generally developed by specialized suppliers rather than by polluting firms, thus weakening the potential to give rise to crowding out effects. Part of the explanation could be attributable to the fact that the markets for renewable energy are still very fragmented, uncertain and underexploited.

To conclude this section, some comment is needed on the generality and scope of the results. All results refer to static and short-term relationship, with no consideration of long run effects of R\&D on innovation output and, more importantly, of innovation output on productivity. In the specific case

\footnotetext{
${ }^{32}$ The reasoning about compliance costs is partly weakened by the use of patents as a measure of environmental innovations. Patent information say nothing about the actual adoption of innovations. It is thus plausible that a substantial amount of environmental patents is filed by specialized suppliers of 'green' technologies and that the underlying innovation will be employed (i.e. adopted) by other firms to reduce compliance costs.
} 
of environmental technologies, it could be the case that static crowding out is counterbalanced by long run positive effects on productivity, especially because the market for environmental technologies is a new market with great potentials for growth.

\section{Concluding remarks}

In this paper I investigate innovation patterns of Italian manufacturing firms, with a specific focus on determinants and productivity effects of environmental innovations. The CDM model describes innovation patterns coherently with expectations. Focusing on environmental innovations, there is evidence of a systematic difference in the effect of usual drivers of innovation output relative to other innovations and a significant bias for environmental innovations by polluting firms and sectors. Moreover, environmental innovations systematically differ from other innovations in their effect on firm's productivity. Environmental innovations either guarantee a return which is substantially lower than that of non-environmental innovations or they slightly reduce labour productivity. This result, coupled with constrained financial resources to be devoted to $\mathrm{R} \& \mathrm{D}$ activities, is a possible evidence of crowding out of environmental innovations relative to non-environmental innovations. It is important to stress that the evidence of crowding out refers to short term indicators of productivity. It is reasonable to assume, however, that the positive effects of policy-induced environmental innovations on competitiveness (and possibly measured productivity) predicted by the 'strong' version of the Porter Hypothesis (Porter and van der Linde, 1995) will show up in the medium-long run because they mainly depend on earlymover advantages of eco-innovators and on the creation of new markets for 'green' technologies.

Further research should be carried out to build a coherent theoretical framework in order to identify the channels through which crowding out occurs. Moreover, these results, based on administrative data and a very reduced set of explanatory variables, should be confirmed by similar models based on more comprehensive data sources such as innovation surveys (e.g. the Community Innovation Survey or other national or regional innovation surveys) for which is generally possible to consider both the creation and the adoption of innovations by firms.

\section{A Polluting firms and polluting sectors}

The AIDA database has been further extended with information on polluting plants and on pollution-intensive sectors. Italian large polluting plants are reported by the EPER (European Pollutant Emission Register) and the EPRTR (European Pollutant Release and Transfer Register) registers. The 
EPER has been introduced by the IPCC (Integrated Pollution Prevention and Control) Directive (96/61/CE). EPER includes all facilities and plants above a certain threshold of air or water pollution. The year of reference is 2006. The E-PRTR substituted the EPER register starting from the year 2007 onwards. The E-PRTR complements information on large polluting plants (used in this paper to identify polluting firms) with diffused emission sources with great details. Differently from the EPER, the E-PRTR includes waste-intensive plants.

To identify pollution intensive sectors, I used information on 18 different types of air emissions ${ }^{33}$ reported at the 2-digit Nace level by the NAMEA (National Accounting Matrix including Environmental Accounts) dataset for Italy (coverage: 1990-2008). I identified as pollution intensive sectors those sectors for which the yearly emissions intensity (emissions per monetary output) for any type of emissions ranked at least fifth for at least five times. I identified as polluting intensive sectors the following 2-digit Nace codes: 15 (Food products and beverages), 16 (Tobacco products), 17 (Textiles), 20 (Wood products), 21 (Pulp and paper), 23 (Coke, refined petroleum and nuclear fuel), 26 (Other non-metallic products), 27 (Basic metals), 30 (Machinery and computers) and 37 (Recycling).

\section{B Adjustments to AIDA}

I deflated firm-level value added to 2000 prices according to a 2-digit value added deflator (Istat). Fixed physical assets, total assets and R\&D were deflated to 2000 prices according to a 2-digit fixed asset deflator (Istat). Market share was computed as the share of firm's reported sales relative to total sales for firms in AIDA in the same 3-digit Nace sector. This is a rough measure because it does not consider either multi-product firms, whose market share is probably overestimated, and the competition by firms not included in AIDA (on average smaller than firms included in the database), leading to a general overestimation. Due to the lack of yearly investment data in AIDA, I use the balance sheet value of fixed physical assets as a measure of capital stock. Finally, my R\&D variable consists in the amount of capitalized $R \& D$ expenditure which is reported within intangible assets. According to the Italian law, the capitalization of $R \& D$ expenditure is voluntary and possible only when the utility of the investment is expected to last for more than one year. Moreover, firms satisfying a combination of requirement correlated to firm size, are allowed to file a reduced-form balance sheet with no separation of R\&D assets within the broader category of intangible assets. This problem of censoring, combined with the usual issue of sample selection in reporting positive $\mathrm{R} \& \mathrm{D}$, is likely to harm seriously

\footnotetext{
${ }^{33}$ Carbon dioxide, N2O, methane, NOx, SOx, ammonia, NMVOC, carbon oxide, particulate matter ( $<10$ micron and $<2.5$ micron) and a series of heavy metals.
} 
the reliability of the $R \& D$ intensity variable. Possible measurement errors might result in over-estimated standard errors in the $R \& D$ equation.

\section{References}

Aghion P, Howitt P (1992) A model of growth through creative destruction. Econometrica 60(2):323-51

Brunnermeier SB, Cohen MA (2003) Determinants of environmental innovation in US manufacturing industries. Journal of Environmental Economics and Management 45(2):278-293

Cainelli G, Mazzanti M, Zoboli R (2011) Environmental innovations, complementarity and local/global cooperation: Evidence from North-East Italian industry. International Journal of Technology, Policy and Management 11(3/4):328-368

Calel R, Dechezlepretre A (2012) Environmental policy and directed technological change: Evidence from the european carbon market. Tech. rep.

Cameron AC, Trivedi PK (1998) Regression Analysis of Count Data. No. 9780521632010 in Cambridge Books, Cambridge University Press

Cohen WM, Klepper S (1996) A reprise of size and R\&D. Economic Journal 106(437):925-51

Crepon B, Duguet E, Mairesse J (1998) Research, innovation, and productivity: An econometric analysis at the firm level. Tech. rep.

Eberhardt M, Helmers C (2010) Untested assumptions and data slicing: A critical review of firm-level production function estimators. Economics Series Working Papers 513, University of Oxford, Department of Economics

Griffith R, Huergo E, Mairesse J, Peters B (2006) Innovation and productivity across four European countries. Oxford Review of Economic Policy 22(4):483-498

Griliches Z (1990) Patent statistics as economic indicators: A survey. Journal of Economic Literature 28(4):1661-1707

Hall B, Lotti F, Mairesse J (2009) Innovation and productivity in SMEs: empirical evidence for Italy. Small Business Economics 33(1):13-33

Hall BH (2006) R\&D, productivity and market value. Tech. rep.

Hall BH, Thoma G, Torrisi S (2007) The market value of patents and R\&D: Evidence from european firms. Tech. rep. 
Horbach J (2008) Determinants of environmental innovation-new evidence from German panel data sources. Research Policy 37(1):163-173

Horbach J, Rammer C, Rennings K (2011) Determinants of eco-innovations by type of environmental impact. The role of regulatory push/pull, technology push and market pull. ZEW Discussion Papers 11-027, ZEW Zentrum fr Europaische Wirtschaftsforschung / Center for European Economic Research

Jaffe A, Newell R, Stavins R (2002) Environmental policy and technological change. Environmental \& Resource Economics 22(1):41-70

Jaffe AB, Palmer K (1997) Environmental regulation and innovation: A panel data study. The Review of Economics and Statistics 79(4):610-619

Johnstone N, Hascic I, Popp D (2010) Renewable energy policies and technological innovation: Evidence based on patent counts. Environmental \& Resource Economics 45(1):133-155

Kemp R, Pearson P (2007) Final report mei project about measuring ecoinnovation. URL http://www.merit.unu.edu/MEI

Lanjouw JO, Mody A (1996) Innovation and the international diffusion of environmentally responsive technology. Research Policy 25(4):549-571

Mansfield E (1986) Patents and innovation: An empirical study. Management Science 32(2):173-181

Marin G (2011) Matching of PATSTAT applications to AIDA firms - discussion of the methodology and results, mimeo

OECD (2011) Patents by regions. http://dx.doi.org/10.1787/data-00509-en

Oltra V, Kemp R, de Vries FP (2009) Patents as a measure for ecoinnovation. Cahiers du GREThA 2009-05, Groupe de Recherche en Economie Thorique et Applique

Pavitt K (1984) Sectoral patterns of technical change: Towards a taxonomy and a theory. Research Policy 13(6):343-373

Popp D (2002) Induced innovation and energy prices. American Economic Review 92(1):160-180

Popp D (2010) Innovation and climate policy. Tech. rep.

Popp D, Newell RG (2009) Where does energy R\&D come from? Examining crowding out from environmentally-friendly R\&D. Tech. rep.

Popp D, Newell RG, Jaffe AB (2009) Energy, the environment, and technological change. Tech. rep. 
Porter ME, van der Linde C (1995) Toward a new conception of the environment-competitiveness relationship. Journal of Economic Perspectives $9(4): 97-118$

Rave T, Goetzke F, Larch M (2011) The determinants of environmental innovations and patenting: Germany reconsidered. Ifo Working Paper Series Ifo Working Paper No. 97, Ifo Institute for Economic Research at the University of Munich

Rennings K (2000) Redefining innovation - eco-innovation research and the contribution from ecological economics. Ecological Economics 32(2):319332

Rennings K, Ziegler A (2004) Determinants of environmental innovations in Germany: Do organizational measures matter? a discrete choice analysis at the firm level. ZEW Discussion Papers 04-30, ZEW - Zentrum fr Europaische Wirtschaftsforschung / Center for European Economic Research

Rexhauser S, Rammer C (2011) Unmasking the porter hypothesis: Environmental innovations and firm-profitability. ZEW Discussion Papers 11-036, ZEW - Zentrum fr Europaische Wirtschaftsforschung / Center for European Economic Research

Wagner M (2007) On the relationship between environmental management, environmental innovation and patenting: Evidence from German manufacturing firms. Research Policy 36(10):1587-1602 


\section{Institution Markets \\ IMT}

INSTITUTE FOR ADVANCED STUDIES LUCCA

2012 ( ) IMT Institute for Advanced Studies, Lucca Piazza San ponziano 6, 5100 Lucca, Italy. www.imtlucca.it 